\title{
Ways to solve the problems of individual vehicle storage in new residential areas of large cities
}

\author{
Ruslan Spodarev ${ }^{1 *}$, and Vladimir Belokurov ${ }^{1}$ \\ ${ }^{1}$ Voronezh State Forestry Engineering University named after G.F. Morozov, 394087 Voronezh, \\ Russian Federation
}

\begin{abstract}
The article discusses ways to solve the problem of storing individual cars. The methodology for calculating the area for garages in the existing residential development, as well as in the formation of new residential areas. The analysis of the patterns in the formation of the optimal ratio between the areas of residence of the population and places of storage of cars is carried out. An integrated approach is proposed to ensure the satisfaction of car owners in places where cars are stored.
\end{abstract}

An increase in the well-being of urban residents and the associated increase in the number of individual vehicles poses a difficult task for urban planners to place parking lots and garages for storing cars in urban areas. All this requires constant improvement of the techniques and principles of urban planning, which is impossible without timely adjustment of the relevant urban planning standards.

Certain provisions of the current guidelines for the placement of parking lots, garages, intercepting parking lots and other types of parking currently need to be clarified and supplemented in order to increase the validity of design solutions and economical use of land resources [1].

Thus, the location of facilities for storing individual vehicles is predetermined by the variety of urban planning conditions. In this regard, an integrated approach to solving this problem involves taking into account such factors as: the growth rate of the car fleet; the level of organization of transport services; availability of car storage places; territorial resources and size of residential units; their number, density, etc. This will make it possible to create a more perfect car storage system, which is one of the most important elements of the functioning of urban transport systems. Such a task should be solved in the process of urban planning and standard design by establishing more substantiated regulatory indicators.

Analysis of the interaction and interdependence of the above factors made it possible to distinguish them into three main groups: urban planning, environmental and economic [2]. To evaluate the design solutions for car storage systems, they should be expressed in quantitative form:

- urban planning - in the form of the area of territories for the construction of garages and parking lots / ha /, transport or pedestrian accessibility / $\mathrm{m}$ or min. /, specific consumption of the territory per one parking space $/ \mathrm{m}^{2}$. Placement of garages and parking lots outside microdistricts, as a rule, is associated with ensuring transport accessibility;

* Corresponding author: spruslan78@mail.ru 
- environmental - the level of air pollution /maximum permissible concentration, $\mathrm{mg} / \mathrm{m}^{3}$ and the level of noise in dBA. These factors are limiting when looking for the smallest possible "neighborhood" of cars and residential areas/.

Economic - reflecting the efficiency of the placement of garages and parking lots in the city, district, microdistrict. They are expressed by the amount of profit received from the use of a place in the garage or parking lot, and are characterized by the level of comfort and improvement of the territory. One of the main ways of rational use of capital investments in garage construction is to increase the efficiency of the use of territories [3].

The economic indicators are characterized by the urban planning indicators of individual structures and the efficiency of the use of the territory, accessibility, as well as sanitation and the concentration of vehicles in various functional areas.

The analysis of the interdependence of factors showed the relative locality of the solution to the problem of organizing a car storage system. This system is characterized by the interconnectedness of the areas of residence of the population and storage of cars. It is designed to fully provide car owners with places to store cars at various levels of motorization, while maintaining optimal accessibility to their places of residence.

However, the existing practice of urban planning does not meet the requirements of the interconnection of the general strategy for the formation of a car storage system with a specific location of garages and parking lots. Therefore, it is necessary to develop a unified policy for the formation of this system at all stages of design and implementation of projects, urban planning [4].

At the stage of preliminary design, a general strategy for the formation of the system should be decided, with the allocation of functional zones for the placement of garages and parking lots, and the stages of its implementation should also be notched.

When developing a project for the development of a new residential area, it is important to provide not only the final decision for organizing the storage of vehicles, but also intermediate stages. This is dictated by the influence of the level of motorization on the storage conditions of cars. Based on the limited territories for placing garages and parking lots and the need to fully provide car owners with places for storing cars, the capacity of garage structures should be gradually increased in accordance with the increase in the level of motorization.

When forming a car storage system, one should proceed from the fact that the consumption of territory for storage places will ensure the need for storage places at a level of individual motorization of 300 or more per 1000 inhabitants, without leaving the residential area. This is the basis of the idea of forming a storage system according to the structural elements of residential areas /residential group, microdistrict, residential area/ not by increasing the area, but by balancing the increase in the capacity of structures depending on the growth of the car park. Moreover, the development of the territory must be carried out from the lower level of the system /residential group/, gradually moving to the higher/ microdistrict, residential area/ [5], [6], [7].

Solving the issues of storing individual vehicles at the level of the city-wide system allows you to determine the territorial needs of the city at the stage of developing a master plan and link them with specific planning solutions at further stages of urban planning.

The studies have shown that the building area and the size of the plots of structures for storing passenger cars belonging to citizens provided for by SNIP allow to provide a promising level of motorization /300 cars per 1000 inhabitants/ [8], [9]. In this regard, the regulatory documents should provide for the allocation of special zones for storing individual vehicles, linked to the planning transport structure of the microdistrict and residential area, which will make it possible to make rational decisions from an urban planning point of view, taking into account the process of forming a storage system for individual vehicles and an increase in the level of motorization. 
In the context of an acute shortage of urban areas, especially in the central regions of the largest cities with existing buildings, it is advisable to stepwise formation of a storage system not through the development of new territories through a balanced increase in the capacity of all storage facilities, depending on the growth in the level of motorization. With this approach, the territorial needs of the storage system depend on the population size of the microdistrict, residential area or city as a whole. The tendency of housing stock downsizing is taken into account in the indicators of the total area of housing, to which the population is reduced.

$$
T_{g a r}^{S}=\frac{a_{g a r}^{R}+1000 H_{t h}}{n \cdot 13,5},
$$

where:

$T_{\text {gar }}^{S}$ - specific consumption of the territory for garages, $\mathrm{m}^{2} /$ author.

$H_{t h}$ - the norm of the total area of housing, $\mathrm{m}^{2} /$ person.

$n$ - level of motorization, auto/1000.

$a_{\text {gar }}^{R}$ - the rate of consumption of the territory from garages and parking lots, $\mathrm{m}^{2} /$ person.

13.5 - the norm of the total area of housing, $\mathrm{m}^{2} /$ person.

When placing storage sites in free areas, two options for the development of specially designated zones are proposed:

- first - open parking - underground garage - combined /ground-underground/ garage of estimated capacity. The entire plot is being developed into an underground garage with one to three underground floors. The supporting structures allow it to be further expanded up to five ground floors;

- the second - an open parking lot - a multi-storey garage combined with an open parking lot a multi-storey garage with an estimated capacity. Sectional building of the site is carried out in stages.

The principles of urban planning rationing, based on a new concept of territorial-spatial formation of a system of permanent storage of individual vehicles in cities, take into account such objective conditions as limited territorial resources, an increase in the level of motorization, etc. comfortable operation of the entire system is achieved. Therefore, the improvement of regulatory and instructive documents on the placement of storage facilities for individual cars in cities will help to introduce these principles into the practice of urban planning.

This provision will contribute to the preservation of the territorial resources of the city as a whole. The level of motorization will influence the choice of the stage of formation of the system, characterized by a specific set of storage facilities with a certain value of the indicator of the specific consumption of territories.

Garages and parking lots in the main planning elements of residential areas should be located in accordance with the normative availability, sanitation, etc. the typology of the structures used and the percentage distribution of parking spaces at various levels of motorization.

Analysis of planning solutions for residential areas and neighborhoods shows that various planning solutions for car storage systems depend on the level of motorization, accessibility, sanitary and hygienic requirements, and consumption of territories.

The planning decision, formed under the influence of these factors, expressed by urban planning indicators (as noted above, they are also urban planning interpretation of environmental and economic indicators), determines the types of structures accepted. This relationship makes it possible to classify planning techniques for organizing a car storage system /table $1 /$ and to bring urban planning and standard design into a single project process of forming a car storage system. 
In general terms, the classification of planning techniques for organizing the storage of cars can be described as follows [10].

The placement of structures in a residential group by types of storage is divided into parking at residential buildings and permanent storage. Parking is carried out in open parking lots and along driveways, on drives at the entrance to a residential group. Permanent storage - in underground or built-in garages.

Table 1. Recommended standards for the construction of vehicle storage areas.

\begin{tabular}{|c|c|c|c|c|}
\hline $\begin{array}{l}\text { Placement of } \\
\text { places (zones) for } \\
\text { storing cars }\end{array}$ & Type of structures & $\begin{array}{l}\text { Capacity, } \\
\text { parking } \\
\text { spaces }\end{array}$ & $\begin{array}{c}\text { Number of } \\
\text { storeys }\end{array}$ & Availability \\
\hline one & 2 & 3 & 4 & five \\
\hline $\begin{array}{l}\text { At the entrance to } \\
\text { the residential } \\
\text { group }\end{array}$ & $\begin{array}{l}\text { The area at the } \\
\text { entrance to the } \\
\text { residential group }\end{array}$ & $\begin{array}{c}\text { No more than } \\
30\end{array}$ & - & Up to $150 \mathrm{~m}$ \\
\hline $\begin{array}{l}\text { In a residential } \\
\text { group }\end{array}$ & $\begin{array}{l}\text { Underground and } \\
\text { built-in garages }\end{array}$ & $20-50$ & 1 & Up to $150 \mathrm{~m}$ \\
\hline $\begin{array}{l}\text { On the periphery } \\
\text { of the microdistrict } \\
\text { on a local } \\
\text { driveway /zone/ }\end{array}$ & $\begin{array}{l}\text { - Car storage areas } \\
\text { - Ground garages } \\
\text { - Multi-storey ground } \\
\text { garages }\end{array}$ & $\begin{array}{l}\text { Up to } 200 \\
\text { Up to } 200 \\
\text { Up to } 500\end{array}$ & 1 & $\begin{array}{l}\text { Up to } 800 \mathrm{~m} \\
\text { /7-12 minutes on } \\
\text { foot/ }\end{array}$ \\
\hline $\begin{array}{l}\text { Dispersed on the } \\
\text { periphery of the } \\
\text { neighborhood }\end{array}$ & $\begin{array}{c}\text { - Car storage areas } \\
\text { - Ground garages } \\
\text { - Underground and } \\
\text { semi-underground } \\
\text { garages } \\
\text { - Multi-storey ground } \\
\text { garages }\end{array}$ & $\begin{array}{l}\text { Up to } 200 \\
\text { Up to } 200 \\
\text { Up to } 100 \\
\text { Up to } 500\end{array}$ & $\begin{array}{l}1 \\
1\end{array}$ & $\begin{array}{c}400-500 \mathrm{~m} \\
\text { /5-6 minutes on } \\
\text { foot/ }\end{array}$ \\
\hline $\begin{array}{l}\text { Outside the } \\
\text { residential area in } \\
\text { the territory of the } \\
\text { planning area } \\
\text { /zone/ }\end{array}$ & $\begin{array}{l}\text { - Multi-storey ground } \\
\text { garages } \\
\text {-Combined garages }\end{array}$ & $\begin{array}{c}1500 \\
\text { Up to } 3000\end{array}$ & $\begin{array}{l}5 \\
6\end{array}$ & $\begin{array}{c}1.5-2.0 \mathrm{~km} \\
/ 20 \text { minutes by } \\
\text { public transport }\end{array}$ \\
\hline $\begin{array}{l}\text { On the periphery } \\
\text { of a residential } \\
\text { area }\end{array}$ & $\begin{array}{l}\text { - Multi-storey ground } \\
\text { garages } \\
\text {-Combined garages }\end{array}$ & $\begin{array}{l}1500 \\
2500\end{array}$ & 5 & $\begin{array}{c}0.8-1.0 \mathrm{~km} \\
/ 15 \text { minutes by } \\
\text { public transport/ }\end{array}$ \\
\hline $\begin{array}{l}\text { Dispersed around } \\
\text { the periphery of a } \\
\text { residential area }\end{array}$ & $\begin{array}{l}\text { - Multi-storey ground } \\
\text { garages } \\
\text {-Combined garages }\end{array}$ & $\begin{array}{l}500 \\
800\end{array}$ & 5 & $\begin{array}{c}0.8-1.0 \mathrm{~km} \\
/ 15 \text { minutes by } \\
\text { public transport/ }\end{array}$ \\
\hline
\end{tabular}

Garages and parking lots located on the periphery of the neighborhoods are concentrated and dispersed. They can be separated from the building by a local passage.

The remoteness of storage places for cars in various structural elements from housing depends on the capacity of the structures being placed. The planning organization of car storage in a residential area, microdistrict and in a residential group determines the typology of structures. For example, large garages should serve the residential area as a whole and are located on the periphery or outside it within a 15-minute walk and transport accessibility [11], [12], [13]. 
Car storage in the city's transport system is an element of service that is inextricably linked with the planning organization of residential areas, in the design system it should be separated into a separate subsystem and should be carried out after the formation of such design subsystems as "residential development", "public buildings", "improvement and landscaping", "pedestrian and transport communications and structures". Although the organization of car storage is included in the subsystem "pedestrian and transport communications and structures", but it is solved in the last turn. At the same time, it is necessary to adapt to the formed compositional solution of the microdistrict, residential area, which worsens the storage system and leads to ineffective use of territories, a decrease in the level of comfort, an increase in the number of cars.

Therefore, the proposed territorial-spatial formation of the storage system according to the structural elements of the residential zone, starting from the lower level /residential group/, should be carried out taking into account the growth of the level of motorization, the limited territorial resources, the established practice of construction, the material and technical level of the construction base [14], [15].

In general, an integrated approach to solving the problem is intended to ensure full satisfaction of the needs of car owners in places for storing cars, comfortable operation of garages and parking lots, saving capital investments in the development of this construction industry.

\section{References}

1. V.P. Belokurov, R.A. Spodarev, S.V. Belokurov, In the collection: TRANSPORTATION RESEARCH PROCEDIA. XIV International Conference on Organization and Traffic Safety Management in Large Cities (OTS-2020). pp. 52-58 (2020)

2. V.P. Belokurov, R.A. Korablev, E.N. Busarin, A.Y. Artemov, R.A. Spodarev, Increase of passive safety of vehicles due to temperature calculation of brake units, Proceedings of the International Conference "Aviamechanical Engineering and Transport" (AVENT2018) (2018) Advances in Engineering Research, 158, pp. 62-66

3. V.P. Belokurov, S.V. Belokurov, R.A. Korablev, A.A. Shtepa, Models of expert assessments and their study in problems of choice and decision-making in management of motor transport processes, Joumal of Physics: Conference Series. Vol. 1015. Issue 3. P. 032132.- International Conference information Technologies in Business and Indastry 2018 (2018)

4. A. Marusin, Methods for assessing the functional efficiency of automated traffic enforcement systems, PhD Thesis in Engineering. Saint Petersburg University of Architecture and Civil Engineering, Saint Petersburg (2017)

5. R.N. Safiullin, M.A. Kerimov, A.V. Marusin, A.V. Marusin, Improving the efficiency of the system of photo and video fixation of administrative offenses in road traffic, Bulletin of Civil Engineers, 3 (56), 233-237 (2016).

6. S. Evtiukov, M. Karelina, A. Terentyev, A method for multi-criteria evaluation of the complex safety characteristic of a road vehicle characteristic of a road vehicle, Transportation Research Procedia, 36, pp. 149-156 (2018)

7. E. Kurakina, S. Evtiukov, J. Rajczyk, Forecasting of road accident in the DVRE system. Transportation Research Procedia, 36, pp. 380-385 (2018)

8. P. Kravchenko, E. Oleshchenko, Mechanisms of functional properties formation of traffic safety systems, Transportation Research Procedia, 20, pp. 367-372 (2017) 
9. A. Kuraksin, A. Shemyakin, S. Borychev, Meso-DTA traffic model technology for evaluating effectiveness and quality of the organization of traffic in large cities, Transportation Research Procedia, 20, pp. 378-383 (2017)

10. A. Shemyakin, A. Kuraksin, A method for studying traffic flow characteristics in the central part of Ryazan based on the global positioning system technologies. Science and Technology in Transport, 4, pp. 91-99 (2016)

11. A. Marusin, A. Marusin and I. Danilov, A method for assessing the influence of automated traffic enforcement system parameters on traffic safety, Transportation Research Procedia, 36, pp. 500-506 (2018)

12. A. Marusin, A. Marusin, T. Ablyazov, Transport infrastructure safety improvement based on digital technology implementation, Atlantis Highlights in Computer Sciences, 1, pp. 353-357 (2019)

13. V.Ya. Builenko, G.N. Klimova, V.A. Zelikov, Yu.V. Strukov, A.Yu Artemov, Methodological approaches to improving the quality of training of drivers of motor vehicles, Science and technology in the road industry, 3 (85), pp. 13-16 (2018)

14. Yu.I. Lobanova, Differentiation of stereotyped perceptions of road users: determining factors, European Social Science Journal,Vol. 2. No. 12. pp. 393-402 (2018)

15. V.P. Belokurov, R.A. Korablev, E.N. Busarin, A.Y. Artemov, R.A. Spodarev, Jncrease of passive safety of vehicles due to temperature calculation of brake unit, Advances in Engineering Research, Vol. 158, pp 62-66 (2018) 